\title{
Analiza działań informacyjnych i promocji Wojsk Obrony Terytorialnej w mediach społecznościowych i na stronie WWW
}

STRESZCZENIE: 1 stycznia 2017 r. weszła w życie ustawa wprowadzająca Wojska Obrony Terytorialnej (dalej WOT) jako jeden z rodzajów Sił Zbrojnych Rzeczpospolitej Polskiej. Celem artykułu jest analiza działań informacyjnych i promocyjnych WOT, które mają bezpośrednie przełożenie na postrzeganie formacji w środowisku ogólnopaństwowym oraz potencjalnych żołnierzy terytorialnej służby wojskowej. W artykule dokonano analizy informacji i działań promocyjnych zamieszczonych na oficjalnej stronie WOT (terytorialsi.wp.mil.pl) oraz na oficjalnych profilach w mediach społecznościowych (Facebook, Twitter, Instagram, Youtube). Efektem analizy materiałów informacyjnych oraz form ich przekazywania jest wniosek, że strona internetowa oraz działania informacyjne WOT, w szczególności na koncie facebookowym, zostały zaprojektowane i wykonane z najwyższą starannością. Sposoby przedstawiania informacji i promocji wpisują się w nowoczesne trendy w tej dziedzinie.

Celem artykułu jest analiza profili WOT w mediach społecznościowych, mająca wykazać, który z nich ma największy zasięg oddziaływania na użytkowników końcowych. Analizie zostały poddane profile WOT pod kątem formy i treści

* Student III roku studiów I stopnia na kierunku architektura informacji, prowadzonych przez Instytut Badań Informacji i Komunikacji na Uniwersytecie Mikołaja Kopernika w Toruniu. 
informacji, z uwzględnieniem jej atrakcyjności dla odbiorców. Ponadto analizie została poddana strona internetowa, uwzględniająca zagadnienia związane z użytecznością oraz architekturą informacji.

SŁoWA KLUCzoWE: informacja, promocja, media społecznościowe, Wojska Obrony Terytorialnej.

\section{Wprowadzenie}

$\mathrm{O}$

cena profili społecznościowych oraz strony internetowej została przeprowadzona na podstawie analizy treści zawartości na poszczególnych profilach oraz witrynie internetowej Wojsk Obrony Terytorialnej. Wojska Obrony Terytorialnej (dalej: WOT) są jednym z pięciu rodzajów sił zbrojnych Rzeczpospolitej Polskiej, które mają w znaczny sposób zwiększyć potencjał obronny Polski. WOT został powołany ustawą z dnia 16 listopada 2016 r. o zmianie ustawy o powszechnym obowiązku obrony Rzeczpospolitej Polskiej oraz niektórych innych ustaw ${ }^{1}$, która weszła w życie 1 stycznia 2017 r. W tej formacji służą żołnierze zawodowi oraz obywatele Polski, pełniący terytorialną służbę wojskową, która jest nowym rodzajem czynnej służby wojskowej. Istotnym czynnikiem zachęcającym społeczeństwo do wstępowania w szeregi WOT jest rodzaj pełnienia służby wojskowej, który jako jedyny rodzaj, jest indywidualnie dopasowany do każdego żołnierza terytorialnej służby wojskowej tak, aby nie kolidował z życiem osobistym i zawodowym. Ponadto WOT kultywuje pamięć i tradycję żołnierzy Armii Krajowej oraz Żołnierzy Wyklętych, propaguje także idee patriotyczne w społeczeństwie.

Podstawowymi zadaniami WOT jest prowadzenie działań obronnych we współdziałaniu z wojskami operacyjnymi, prowadzenie samodzielnych działań przeciwdywersyjnych i przeciwdesantowych, realizacja przedsięwzięć z zakresu zarządzania kryzysowego oraz prowadzenie działań informacyjnych. WOT w obecnej sytuacji geopolitycznej stanowi szybki i skuteczny sposób na odbudowę militarnego potencjału sił zbrojnych

1 Ustawa z dnia 16 listopada 2016 r. o zmianie ustawy o powszechnym obowiązku obrony Rzeczpospolitej Polskiej oraz niektórych innych ustaw. Dz. U. 2016, poz. 1534. 
w Polsce, co przekłada się jednocześnie na poprawę bezpieczeństwa państwa ${ }^{2}$.

WOT jako że jest stosunkowo nową formacją, która w głównej mierze opiera się na żołnierzach terytorialnej służby wojskowej, szczególną uwagę poświęca działaniom informacyjnym i promocyjnym. Aby odpowiednio rozpatrywać owe działania, należy zacząć od definicji informacji.

Informacja jest to stopień uporządkowania (lub zorganizowania) układu"3.

Działania informacyjne mają więc na celu przedstawianie konkretnych informacji w sposób zrozumiały dla potencjalnego odbiorcy komunikatu.

Działania informacyjne WOT koncentrują się na użyciu mediów społecznościowych, starając się wykorzystywać ich potencjał, który współcześnie przybiera różne formy, m.in. blogów, sieci biznesowych, projektów zespołowych, biznesowych sieci społecznościowych, forów dyskusyjnych, mikroblogów, portali umożliwiających udostępnianie zdjęć, a także recenzowanie produktów/usług, zakładek społecznościowych, gier społecznościowych, portali (serwisów) społecznościowych, portali umożliwiających udostępnianie video oraz wirtualnych światów4. Ponadto media społecznościowe są również coraz chętniej wykorzystywane na szeroką skalę $\mathrm{w}$ działaniach public relations przez przedsiębiorstwa, realizujące cele sprzedażowe ${ }^{5}$.

${ }^{2}$ FAQ - Struktura i zadania, [online] [dostęp 6 stycznia 2019]. Dostępny w World Wide Web: https://terytorialsi.wp.mil.pl/faq/struktura-i-zadania.

3 Mały słownik cybernetyczny, pod red. M. Kempisty, Warszawa 1997.

4 T. Aichner, F. Jacob, Measuring the Degree of Corporate Social Media Use, „International Journal of Market Research" 2015, 57 (2), s. 257-275.

${ }^{5}$ M. Kaczmarek-Śliwińska, Public relations w przestrzeni mediów społecznościowych. Działania organizacji i jej pracowników, Koszalin 2013. 


\section{Analiza profili mediów społeczościowych wykorzystywanych przez WOT}

\section{Facebook}

Pierwszym profilem WOT w mediach społecznościowych, który poddałem analizie, jest oficjalny profil na platformie Facebook. Jest to serwis społecznościowy, założony 4 lutego 2004 r., w ramach którego jego użytkownicy, którzy założyli konto, mogą dzielić się wiadomościami, zdjęciami, filmami z innymi użytkownikami. Otrzymują także dostęp do aplikacji, będących własnością Facebooka. Użytkownicy mogą tworzyć konwersację oraz grupy dyskusyjne, a także strony o charakterze zgodnym z regulaminem Facebooka. Oficjalny profil WOT na Facebooku został założony 1 stycznia $2017 r^{6}$ Tego dnia został zamieszczony pierwszy wpis, który w atrakcyjny i zrozumiały sposób informuje o tym, czym jest WOT oraz jakie informacje będą się ukazywały na profilu.

Pierwszy post pokazuje wyraźny kierunek prowadzenia profilu przez WOT, swoistego stworzenia więzi z odbiorcami komunikatów i informacji. WOT podkreśla w swoich postach rolę ludzi, jako największego potencjału i niezastąpionego składnika formacji. Na profilu posty mają różne formy oraz przekazują wiele informacji. WOT, oprócz postów o prostej formie, często publikuje informacje za pomocą dostępnych narzędzi wizualizacji danych. Dzięki temu informacje są atrakcyjne w odbiorze dla użytkowników. Dobrym przykładem postów o charakterze informacyjnym są posty, informujące o warunkach atmosferycznych w Polsce w czasie kiedy odbywają się szkolenia WOT. Wszystkie najważniejsze informacje pogodowe dla żołnierzy WOT są zawarte w infografice ${ }^{7}$. Infografika z serii pogodowy radar terytorialsa, została wykonana w atrakcyjny graficznie sposób. Wewnątrz obrysu radaru został umieszczony kontur Polski, wraz

${ }^{6}$ Facebook. [w:] Wikipedia, wolna encyklopedia [online] [dostęp 21 stycznia 2019]. Dostępny w World Wide Web: https://pl.wikipedia.org/wiki/Facebook\#cite_note-6.

7 Infografika - wizualizacja danych lub myśli, która pozwala przekazać odbiorcom złożone informacje w taki sposób, by można je było szybko przyswoić i z łatwością zrozumieć. Ponadto Mark Smiciklas pisze że „proces tworzenia i publikowania infografiki określa się mianem wizualizacji danych, projektowania informacji bądź architektury informacji" za: M. Smiciklas, Infografiki: praktyczne zastosowanie w biznesie, Gliwice 2014. 
z podziałem na poszczególne województwa. Informacje o temperaturze i warunkach pogodowych są umieszczone w konturze dla danego województwa, zaś cała legenda wszystkich ikon zastosowanych w infografice została umieszczona po prawej i lewej stronie mapy Polski. Dzięki zastosowaniu ikon, użytkownik może szybko zapoznać się z najważniejszymi dla niego informacjami. Infografika została wykonana w przeważającej kolorystyce ciemnozielonej, która nadaje jej militarnego charakteru. Całość infografiki jest wykonana z dbałością o szczegóły oraz aspekty wizualne.

\section{Wojska Obrony Terytorialnej \\ 1 stycznia 2017 .}

\section{PROFIL WOJSK OBRONY TERYTORIALNEJ.}

Naszym celem jest nie tylko rzetelne informowanie o naszych działaniach, ale także szeroko pojęta edukacja, mająca na celu zmianę klasycznego sposobu myślenia o bezpieczeństwie w dzisiejszych czasach.

Niekonwencjonalne, rozproszone w czasie i przestrzeni społecznej, geograficznej oraz wirtualnej - takie są dzisiejsze formy zagrożeń, wobec których należy stosować adekwatne formy reagowania. Zapraszamy do śledzenia naszych informacji, wskazówek, linków i publikacji. Ich adresatem będą kandydaci na żołnierzy WOT, żołnierze tej formacji i całe społeczeństwo naszego kraju z podziałem na społeczności lokalne, w ramach i na rzecz których my, „Terytorialsi”, będziemy służyć i działać. Profil ten ma być również narzędziem komunikacji bezpośredniej. Działania i struktury Wojsk Obrony Terytorialnej są ukierunkowane na zapewnienie bezpieczeństwa i wspieranie społeczności - jego budowa z założenia nie może być procesem jednostronnym, gdyż będzie wymagała współpracy i wsparcia ze strony obywateli. Dlatego wszelkie konstruktywne informacje zwrotne będą dla nas cenne. Wojska Obrony Terytorialnej nie są i nigdy nie będą sztucznie generowanymi bytami w próżni społecznej - będą częścią systemu obronnego państwa, ale przede wszystkim częścią społeczeństwa. To, jak będą wyglądały, naprawdę zależy od ludzi, którzy będą te struktury współtworzyć. Stań się zatem jednym z nas i miej na to wpływ! Wszystko, co nowe, potrzebuje czasu na przekonanie do zasadności swojego istnienia. Liczymy więc na Twoje bezpośrednie zaangażowanie w projekt lub wspieranie naszych działań w innej formie. Prosimy o zapoznanie się z regulaminem profilu, którego zasad będziemy przestrzegać.

Pozostań na nasłuchu!

Ilustracja 1. Pierwszy post na profilu WOT na Facebooku Źródło: https://www.facebook.com/pg/Terytorialsi/posts/?ref=page_internal 


\section{Wojska Obrony Terytorialnej}

18 stycznia 2019

\section{RADAR POGODOWY 19/20 STYCZNIA}

Przed Wami kolejny szkoleniowy weekend. Już jutro ruszacie skoro świt na szkolenia rotacyjne, podstawowe i wyrównawcze.

W nocy temperatura spadnie poniżej zera, dlatego ostrzegamy Was przed ciężkimi warunkami drogowymi jakie możecie zastać o poranku. Może być ślisko. Pamiętajcie, bezpieczeństwo to podstawa.

Szerokiej drogi!

\#Terytorialsi



Ilustracja. 2. Radar pogodowy 19/20 stycznia 2019 r.

Źródło: https://www.facebook.com/Terytorialsi/photos/a.393659774310890 /917834291893433/?type=3\&theater.

Ponadto na profilu występują posty o charakterze promocyjnym, w których zachęca się do wstąpienia do WOT. Ostatni z takich postów 
skierowany był do studentów oraz uczniów, chcących wstąpić w szeregi WOT. Z myślą o nich WOT daje możliwość odbycia szkolenia wojskowego w czasie ferii zimowych. Informacja została przedstawiona również w postaci infografiki, która w prosty i przejrzysty sposób dostarcza wszystkich niezbędnych informacji dla osób chcących wziąć udział w szkoleniu. Po lewej stronie mapy, w krótki sposób wyszczególniono etapy, które należy wykonać, zaś na samej mapie zostały umieszczone daty prowadzenia szkoleń przez brygady WOT, z podziałem na województwa. Post ma formę wydarzenia, możemy się z nim zapoznać oraz zapraszać innych użytkowników, naszych znajomych do wzięcia udziału w wydarzeniu. Dzięki temu zasięg wydarzenia zwiększa się.

\section{Wojska Obrony Terytorialnej • Przez FERIE do WOT}

\section{PRZEZ FERIE DO WOT}
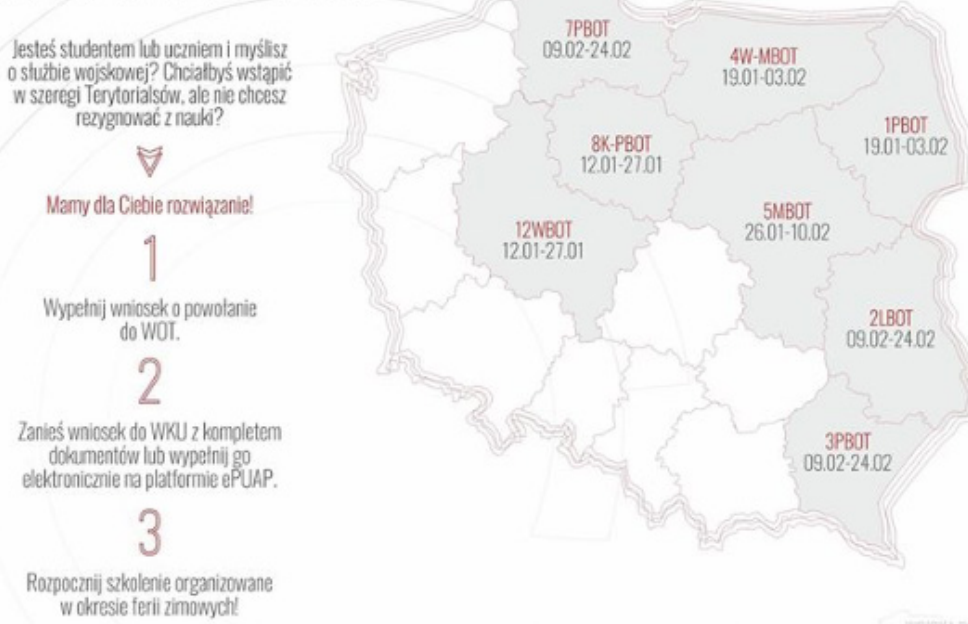

Ilustracja 3. Przez ferie do WOT

Źródło: https://www.facebook.com/Terytorialsi/photos/gm.1112673778939 939/891287024548160/?type=3\&theater 
Kolejnym, istotnym czynnikiem w mediach społecznościowych jest zasięg. Oficjalny profil WOT polubiło 39345 osób, zaś łączna liczba obserwujących profil wynosi 40840 osób $^{8}$. Profil jest prowadzony na bieżąco, o czym świadczą posty, które są systematycznie dodawane. Facebook WOT stanowi wartościowe źródło informacji o formacji i kwestiach z nią związanych oraz jest źródłem promowania formacji w świadomości i opinii społecznej.

\section{Tweeter}

Kolejnym medium społecznościowym, poddanym analizie, jest Twitter. Jest to serwis społecznościowy, który oferuje swoim użytkownikom usługę mikroblogowania. Platforma została założona 21 marca 2016 r. przez Jack’a Dorseya, Ev’a Williamsa oraz Big Stone’a. Użytkownik, który zarejestrował się w serwisie społecznościowym, może wysyłać i odczytywać krótkie wiadomości tekstowe, zwane tweet-ami, wyświetlające się na profilu autora wiadomości. Usługa daje także możliwość tagowania oraz odpowiadania innym użytkownikom na wiadomości ${ }^{9}$.

Profil WOT na platformie Twitter powstał w styczniu 2017 r., tak jak profil na Facebooku. Na profilu WOT obecnie znajduje się 1556 tweetów ${ }^{10}$, które mają formę krótkich wpisów, najczęściej połączonych ze zdjęciem lub materiałem wideo.

Obecnie profil na Tweeterze obserwuje 8035 osób, zaś polubiło go 278 osób. Na profilu znajduje się 1228 filmów i zdjęć ${ }^{11}$. Można zauważyć, że profil WOT na Tweeterze ma mniejszy zasięg i popularność niż na Facebooku. Najprawdopodobniej fakt ten spowodowany jest tym, że Facebook jest bardziej popularnym medium społecznościowym. Na profilu znajdziemy tweety, dotyczące bieżących informacji i wydarzeń. Tweety są nośnikami krótkich informacji, z którymi użytkownik może zapoznać się w krótkim czasie. Tweety informują użytkowników o sze-

8 Stan na dzień 03.02.2019 r.

9 Twitter. [w:] Wikipedia, wolna encyklopedia [online][dostęp 3 lutego 2019]. Dostępny w World Wide Web: https://pl.wikipedia.org/wiki/Twitter.

${ }_{10}$ Stan na dzień 03.02.2019 r.

11 Stan na dzień 03.02.2019 r. 
rokiej działalności formacji oraz o możliwości uczestniczenia w licznych wydarzeniach o charakterze charytatywnym bądź kulturowym, których organizatorem jest WOT. Oprócz wartości informacyjnej, posiadają one także dużą wartość promocyjną, która wpływa bezpośrednio na wzrost popularności oraz wzrost zainteresowania formacją wśród społeczeństwa. Zachęcają jednocześnie osoby zainteresowane służbą wojskową do wstąpienia w jej szeregi. Profil jest prowadzony na bieżąco, o czym świadczą regularnie dodawane tweety.

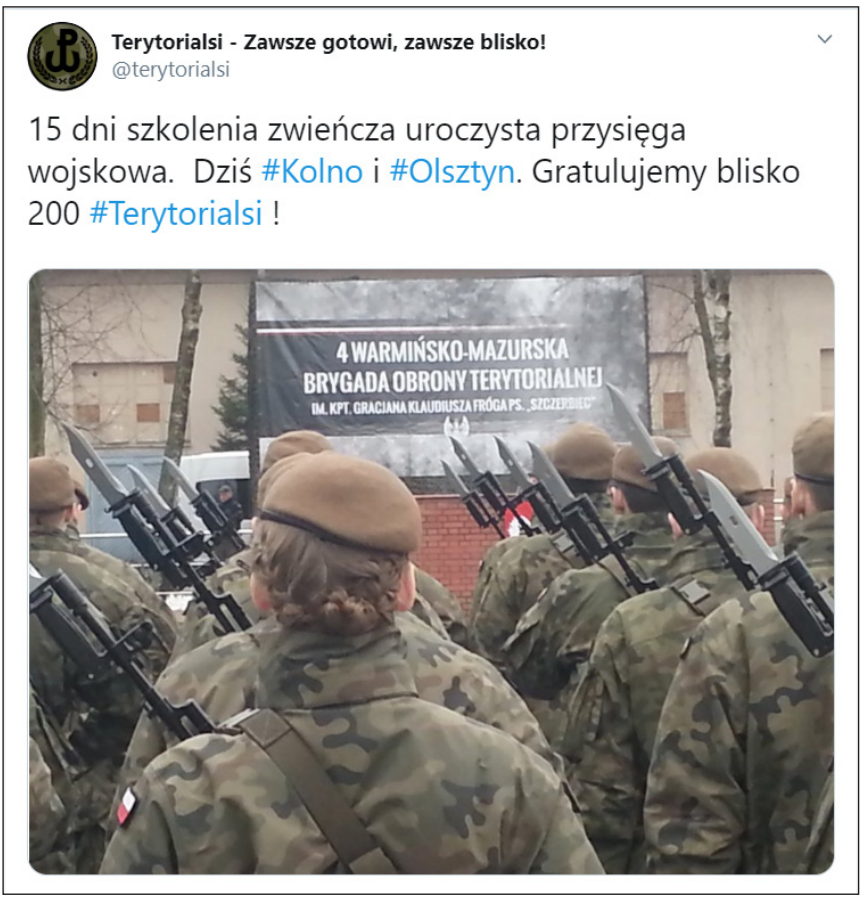

Ilustracja. 4. 15 dni szkolenia zwieńcza uroczysta przysięga wojskowa Źródło: https://twitter.com/terytorialsi

\section{YouTube}

Kolejną platformą, poddaną analizie, jest YouTube. Jest to serwis internetowy założony 14 lutego 2005 r. Autorami YouTube są Jawed Karim, 
Chad Hurley oraz Steve Chen. Właścicielem serwisu jest firma Google ${ }^{12}$. Serwis oferuje swoim użytkownikom bezpłatne umieszczanie, odtwarzanie, ocenianie oraz komentowanie filmów. Użytkownik ma dostęp do oglądania filmów, bez konieczności zakładania konta i logowania się ${ }^{13}$.

WOT posiada swój oficjalny kanał na YouTube od 5 czerwca 2017 r. Obecnie na jego kanale znajduję się 51 filmów, a łączna liczba wyświetleń wynosi 308104. Ponadto, kanał został subskrybowany przez 2353 osoby ${ }^{14}$. W serwisie YouTube nośnikiem informacji są materiały wideo. Materiały wideo na kanale WOT mają charakter informacyjno-promocyjny. Są to często materiały przybliżające sylwetki żołnierzy terytorialnej służby wojskowej, vlogi, a także materiały motywacyjne zachęcające do aktywności fizycznej. Mają one pozwolić na lepsze przygotowanie do testów sprawnościowych, organizowanych dla kandydatów do służby w WOT.

\section{Instagram}

Kolejną platformą społecznościową poddaną analizie jest Instagram, założony w 2010 r. Jego twórcami są Kevin Systrom oraz Mark Krieger. Serwis jest własnością firmy Facebook ${ }^{15}$. Jest to fotograficzny serwis społecznościowy, który po założeniu konta umożliwia użytkownikowi edycję zdjęć oraz filmów, stosowanie do nich filtrów cyfrowych oraz udostępnianie ich w serwisach społecznościowych ${ }^{16}$.

Profil WOT na Instagramie powstał w 2017 r. Pierwszy post został zamieszczony 7 lipca $2017 \mathrm{r}^{17}$ Obecnie profil WOT jest obserwowany przez 7600 użytkowników. Od początku istnienia profilu zostało na nim zamieszczonych 337 postów ${ }^{18}$. Oprócz standardowych postów,

12 Od 10 października 2006 r. YouTube stał się własnością firmy Google.

13 YouTube. [w:] Wikipedia, wolna encyklopedia [online] [dostęp 5 lutego 2019]. Dostępny w World Wide Web: https://pl.wikipedia.org/wiki/YouTube

14 Stan na dzień 5.02.2019 r.

15 Od kwietnia 2012 r. serwis Instagram stał się własnością firmy Facebook.

${ }^{16}$ Instagram. [w:] Wikipedia, wolna encyklopedia [online] [dostęp 5 lutego 2019]. Dostępny w World Wide Web: https://pl.wikipedia.org/wiki/Instagram\#cite_note-2.

17 Profil WOT na Instagramie [online] [dostęp 17 listopada 2019]. Dostępny w World Wide Web: https://www.instagram.com/wojska_obrony_terytorialnej/?hl=pl.

${ }_{18}$ Stan na dzień 9.02.2019 r. 
na profilu są umieszczane regularnie informacje $\mathrm{w}$ formie relacji, czyli szybkiej informacji zdjęciowo-tekstowej. Głównym nośnikiem informacji na Instagramie są zdjęcia. Fotografie umieszczane na profilu WOT mają w znacznej mierze charakter promocyjny. Fotografie są wykonane w dobrej jakości, w profesjonalnych ujęciach oraz mają dużą wartość estetyczną i artystyczną. Odwołują się do codziennych zmagań żołnierzy terytorialnej służby wojskowej, a także przywiązania WOT do spuścizny kultury i tradycji Armii Krajowej. Instagram jest prowadzony na bieżąco, o czym świadczą dodawane regularnie posty i relacje.

\section{Oficjalna strona internetowa WOT}

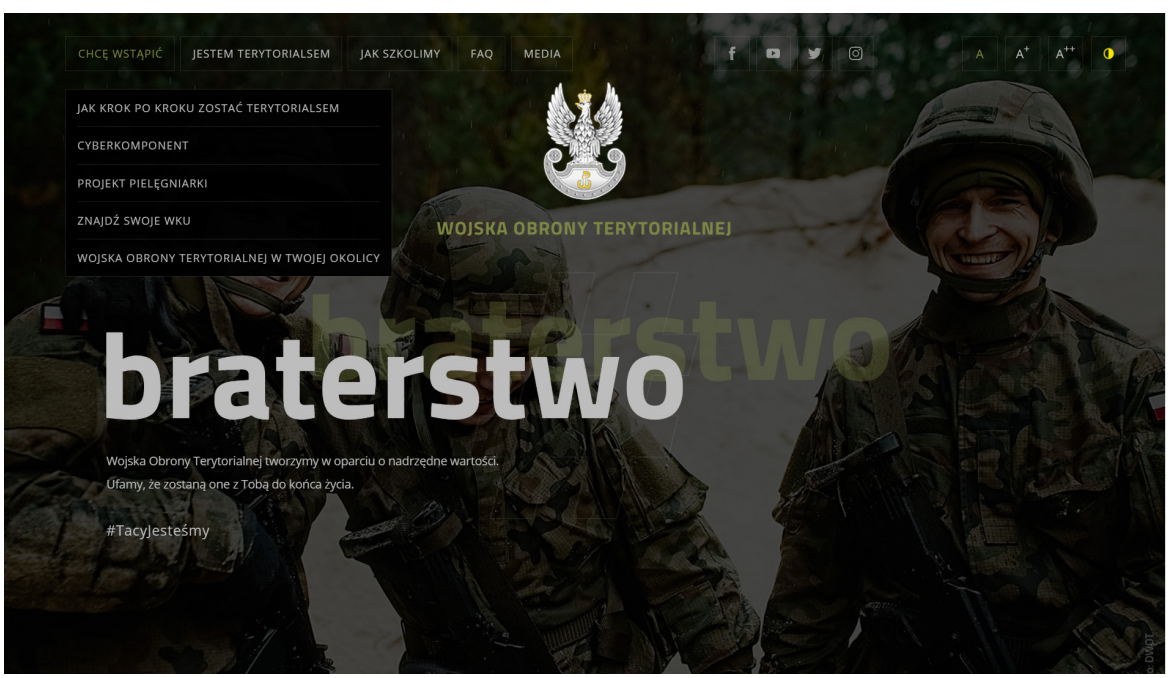

Ilustracja. 5. Strona główna witryny WOT

Źródło: https://terytorialsi.wp.mil.pl/

Analizie została poddana także oficjalna strona internetowa $\mathrm{WOT}^{19}$. Witryna została założona w 2018 r. Strona jest nastawiona na rzetelne

19 Oficjalna strona WOT [online] [dostęp 17 listopada 2019]. Dostępny w World Wide Web: https://terytorialsi.wp.mil.pl/. 
przedstawienie wszelkich informacji związanych z WOT. Została zaprojektowana z myślą o jej użytkownikach, co potwierdza jej struktura. Po wejściu na stronę widzimy prosty, przejrzysty pasek globalnego systemu nawigacji, który dodatkowo po najechaniu kursorem myszy na konkretną zakładkę rozwija się, dając użytkownikowi dostęp do pozostałych podkategorii. Pasek globalnego systemu nawigacji przesuwa się w dół wraz ze scrollowaniem, co umożliwia użytkownikowi dostęp do kategorii w dowolnym momencie przeglądania strony. W logo WOT, po lewej stronie systemu nawigacji, zostało umieszczone łącze do strony głównej. Użytkownik dostaje między innymi dostęp do informacji jak wstąpić w szeregi WOT oraz jakie kryteria należy spełnić by zostać żołnierzem terytorialnej służby wojskowej. Znajdzie tam także dokładne informacje na temat szkolenia oraz roli WOT w systemie obronnym RP oraz opis struktury tej formacji. Co ważne, z punktu widzenia odbiorcy informacji, w zakładce „FAQ” mamy zebrane najczęściej zadawane pytania dotyczące WOT, wraz z odpowiedziami. Dzięki takiemu rozwiązaniu, odpowiedzi na pewne pytania użytkownik może otrzymać jeszcze szybciej. Dostęp do informacji na stronie jest ułatwiony przez zastosowanie modelu hierarchicznego, szerokiego płytkiego, który umożliwia szybkie i proste przeglądanie podkategorii globalnego systemu nawigacji. Co istotne, z punktu widzenia architektury informacji, witryna posiada dostosowania dla osób z niepełnosprawnościami wzroku, co w znaczący sposób wpływa na jej dostępność. Użytkownik ma możliwość zwiększenia dwukrotnie wielkości liter na stronie oraz skorzystania z jej kontrastowej wersji, w której białe napisy przybierają żółty kolor, prostszy do odczytania dla osób słabowidzących. Użytkownik ma dostęp do ustawień, w górnej części ekranu po prawej stronie, dzięki czemu nie musi ich szukać w głębi strony. W górnej części witryny, jak i w stopce, znajdziemy linki w formie ikon do profili WOT w mediach społecznościowych (Facebook, YouTube, Tweeter, Instagram). Witryna jest w całości wykonana starannie, nie posiada żadnych błędów, które miałyby wpływ na użytkowanie jej zasobów informacyjnych. Design strony został wykonany w sposób nowoczesny i atrakcyjny graficznie. Na stronie zostały również zastosowane przejścia ruchomych haseł oraz zmieniające się obrazy w tle strony głównej. Strona ma wysoki poziom merytoryczny oraz jest dobrze dostosowana do potrzeb różnych typów użytkowników. 


\section{Podsumowanie}

WOT od początku swojego powstania kładł duży nacisk na promocję oraz szeroko pojęte działania informacyjne. Posiada swoje oficjalne profile w najpopularniejszych mediach społecznościowych, co ma duży wpływ na promocję oraz na rozpowszechnianie informacji dotyczących działaności tej formacji. Oficjalne profile WOT znajdują się na platformach Faceebok, Tweeter, Instagram oraz YouTube. Działania informacyjno-promocyjne miały wpływ na wzrost zainteresowania WOT-em przez ich użytkowników. Duży wpływ na popularność poszczególnych profili miał zasięg oddziaływania postów, który określa liczba odbiorców, do których treści trafiały. Poniższy wykres obrazuje zasięg profili WOT w wybranych mediach społecznościowych.

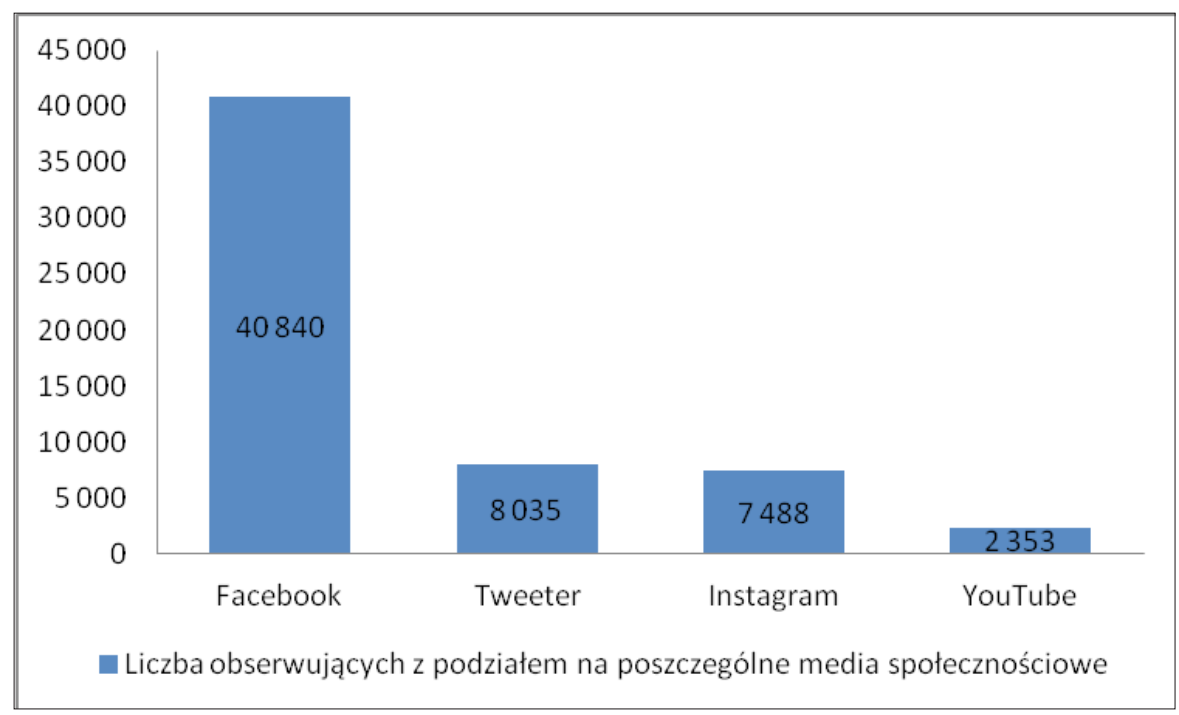

Wykres 1. Zasięg - liczba użytkowników obserwujących profile WOT w poszczególnych mediach społecznościowych (w okresie 3.02-5.02.2019 r.)

Źródło: oprac. własne 
Z danych zebranych podczas analizy wywnioskować można, iż największy wpływ działań informacyjno-promocyjnych WOT w mediach społecznościowych dotyczy użytkowników platformy Facebook. To właśnie profil WOT na Facebooku zyskał największą popularność wśród użytkowników mediów społecznościowych. Obecność profili WOT na wszystkich czterech platformach społecznościowych przyczynia się do jeszcze większego zasięgu oddziaływania informacji i promocji WOT. Strona internetowa WOT jest nastawiona na udzielenie użytkownikowi wszystkich niezbędnych dla niego informacji dotyczących tej formacji. Ponadto, witryna ta posiada dobrze zaprojektowaną architekturę informacji, która przekłada się na proste korzystanie z jej zasobów. Strona posiada także dostosowania dla osób słabowidzących. Podsumowując, WOT prowadzi działania o charakterze informacyjnym i promocyjnym w sposób dobry i profesjonalny.

\section{Bibliografia}

Aichner Thomas, Jacob Frank, Measuring the Degree of Corporate Social Media Use, „International Journal of Market Research” 2015, nr 57 (2), s. 257-275. Facebook. [w:] Wikipedia, wolna encyklopedia [online] [dostęp 21 stycznia 2019].

Dostępny w World Wide Web: https://pl.wikipedia.org/wiki/Facebook. FAQ-Struktura i zadania [online] [dostęp 6 stycznia 2019]. Dostępny w World

Wide Web: https://terytorialsi.wp.mil.pl/faq/struktura-i-zadania.

Instagram. [w:] Wikipedia, wolna encyklopedia [online] [dostęp 5 lutego 2019].

Dostępny w World Wide Web: https://pl.wikipedia.org/wiki/Instagram.

Kaczmarek-Śliwińska Monika, Public relations w przestrzeni mediów społeczno-

ściowych. Działania organizacji i jej pracowników, Koszalin 2013.

Kaplan Andreas, M., Haenlein Michael, Users of the world, unite! The challenges and opportunities of Social Media, „Business Horizons” 2010, nr 53 (1), s. 59-68. Mały słownik cybernetyczny, pod red. Marii Kempisty, Warszawa 1997.

Media społecznościowe. [w:] Słownik języka polskiego PWN [online] [dostęp 14 stycznia 2019]. Dostępny w World Wide Web: http://sjp.pwn.pl/slowniki/ media\%20spo\%C5\%82eczno\%C5\%9Bciowe.html.

Smiciklas Mark, Infografiki: praktyczne zastosowanie w biznesie, Gliwice 2014. Twitter. [w:] Wikipedia, wolna encyklopedia [online] [dostęp 3 lutego 2019]. Dostępny w World Wide Web: https://pl.wikipedia.org/wiki/Twitter. 
Ustawa z dnia 16 listopada 2016 r. o zmianie ustawy o powszechnym obowiązku obrony Rzeczpospolitej Polskiej oraz niektórych innych ustaw. Dz. U. 2016, poz. 1534.

YouTube. [w:] Wikipedia, wolna encyklopedia [online] [dostęp 5 lutego 2019]. Dostępny w World Wide Web: https://pl.wikipedia.org/wiki/YouTube.

\section{Analise of information and promotion activities in social media and on the website of Territorial Defense Forces}

ABSTRACT: On January 1, 2017, the act that introduced the Territorial Defense Force as one of the types of the Polish Armed Forces entered into force. The aim of the paper is to analyze informational and promotional activities of Territorial Defense Forces, which have a direct impact on the perception of formation in the national environment and potential soldiers of territorial military service. The report analyzes the information and promotional activities posted on the official website of the Military Territorial Defense (terytorialsi.wp.mil.pl) and on the official profiles of the Military Territorial Defense in social media (Facebook, Twitter, Instagram, You Tube). The effect of the analysis of information materials and the forms of their transmission is the conclusion that the website and information activities, in particular on the Military Territorial Defense Facebook account, have been designed and made with the utmost care. The ways of presenting information and promotion of the Territorial Defense Forces are in line with modern trends in this field.

KEYWORDS: information, promotion, socialmedia, Territorial Defense Forces. 